\title{
LOS AZULEJOS DE LA CAPILLA DEL CASTILLO DE XÀTIVA
}

\author{
Mercedes González Teruel \\ Universitat de València
}

\begin{abstract}
Resumen: En el recinto del actual castillo de Xàtiva (València), se encuentra una pequeña capilla cuyo interior está decorado de acuerdo con un programa de imágenes dispuesto por el último matrimonio que habitó el castillo. Nuestro interés se centra en el zócalo de las paredes revestido por azulejos valencianos realizados en la fábrica de José Gimeno de Manises (Valencia) en 1948. El estudio de esta obra cerámica, incidirá sin duda, en la conservación de un conjunto muy cuidado en su realización y único en el entorno patrimonial de Xàtiva.
\end{abstract}

Palabras clave: Xàtiva, castillo, azulejos valencianos.

\section{The tiles of the Chapel of the Castle of Xàtiva}

Astract: Inside the current enclosure castle of Xàtiva(València), there is a small chapel whose interior is decorated according to a program of images arranged by the last married couple that inhabited the castle. Our interest is focused on the tile wainscoat by Valencian tiles made in the factory of José Gimeno de Manises (València) in 1948. The study of this ceramic work will undoubtedly affect the historic preservation of a very careful set in its realization and unique in the cultural heritage of Xàtiva.

Key words: Xàtiva, castle, tiles of Valencia.

El castillo de Xàtiva es uno de los monumentos más importantes del ámbito patrimonial valenciano. Ha llegado a nuestros días reconstruido, mostrando sus piedras, sus ruinas, y las huellas de su glorioso pasado. Sobre la sierra situada en lo alto de la ciudad, el recinto se divide en el castell menor, la parte más antigua del castillo, y el castell major, la parte más amplia y significativa. En el comienzo de esta última zona del actual castillo nos llama la atención una pequeña capilla construida con el mayor esmero y cuidado, dedicada a las respectivas advocaciones de sus promotores, San Jorge y la Virgen del Perpetuo Socorro.

Históricamente, la fortaleza llegó a tener dos capillas, una, en el castell major, bajo la advocación de Nuestra Señora ${ }^{1}$ deriva de la obra original de 1276, que

Data de recepció: 14 d'abril de 2020 / Data d'acceptació: 3 d'agost de 2020.

${ }^{1}$ El rei Jaume I estipuló que “...des que hem rescatat ...el Castell de Xàtiva ...hem instituit una capellania a la Capella de Santa María en el Castell... amb un clergue per a l'ofici diví durant el día y durant la nit...", Jaume I (Belenguer, 2007). 
entre 1431 y 1434 fue reconstruida por orden de la Reina María, esposa de Alfonso V el Magnánimo. De construcción gótica, la base del edificio es de forma cuadrilonga de una sola nave con tres bóvedas de crucería, cuyos arcos se apoyan en ménsulas blasonadas con el escudo de Aragón. La segunda capilla, la del castell menor, bajo el título de Santa Ana (Sarthou, 1922: 55) todavía existía en el siglo XVII (Imagen 1), y sobre la que posiblemente se construyó la actual capilla del castillo.

La fortaleza es adquirida en 1947 por Gregorio Molina Ribera, quién como propietario, realiza varias reformas, organizando calzadas, jardines y estancias. Entre estas reformas se encuentra la construcción de una capilla, de estilo neogótico, dedicada al culto particular de su propietario. La capilla está situada en lo alto de seis escalones, detrás de la vivienda principal, y justo al comienzo del castell major. La fachada del edificio, dividida en tres partes, muestra un aspecto de fortaleza idealizada, con el muro imitando la sillería y el techo adornado con almenas defensivas. El proyecto, sin duda, debió ser muy importante para los promotores de la construcción por lo cuidado de los detalles y la calidad de los mismos. Mirando la fachada (Imagen 2) de izquierda a derecha, una espadaña con su campana y rematada por una cruz, señala donde se encuentra el espacio que contiene la diminuta sacristía. La puerta de entrada se adorna con un arco ojival con tracerías en el exterior y rematado por la figura de san Jorge matando al dragón en relieve. Nada se ha dejado al azar, incluyendo las gárgolas fantásticas que rematan las esquinas como vierteaguas del tejado.

$\mathrm{Al}$ entrar, la estancia, que mide en planta seis por cuatro metros aproximadamente (Imagen 3), se encuentra completamente decorada. El pavimento, de mármol, lleva una sencilla estrella jugando con los colores blanco y negro de la piedra. Las pinturas del techo se centran en la filacteria Ave Maria Gratia Plena que sujetan dos angelotes entre nubes y que, a su vez, escoltan a la imagen de la Virgen alada portando en sus manos un escudo con el anagrama de María. El espacio está concebido según un programa organizado conceptualmente, aunque su estilo sea diferenciado. Las pinturas de los muros y del techo, el retablo central dorado y tallado, las vidrieras y el zócalo de azulejos, no siguen una misma línea estética según la concebimos actualmente, sin embargo, su calidad es excelente, y responderían a la demanda de su promotor.

A ambos lados del arco de la entrada, en su interior, en el vano que tapan las dos alas de madera de la puerta encontramos dos inscripciones que ofrecen una valiosa información sobre la autoría de la obra (Imagen 4). A la izquierda se lee "Capilla dedicada al culto de la Santísima Virgen del Perpetuo Socorro, en Mayo de 1948, por deseo de los esposos D. Gregorio Molina, y Da Magdalena Albero". De esta manera, sabemos con certeza la fecha de construcción, el culto a quien se dedica, y los nombres de los comitentes. A la derecha, de 


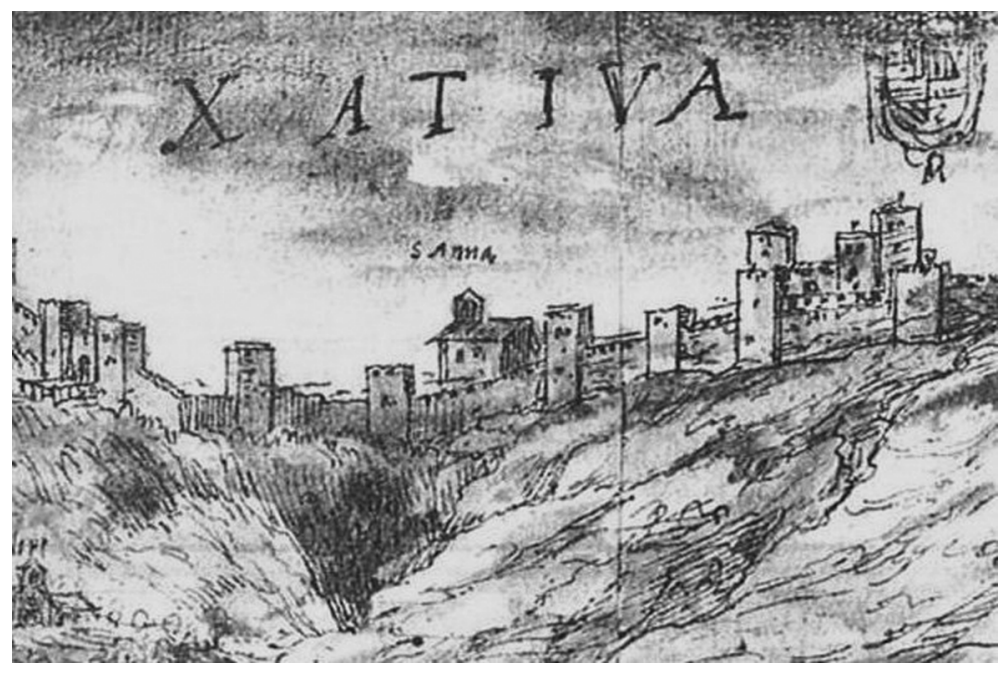

Imagen 1. Detalle del grabado de A. Wyngaerde (1564) con la situación de la capilla dedicada a Santa Ana.

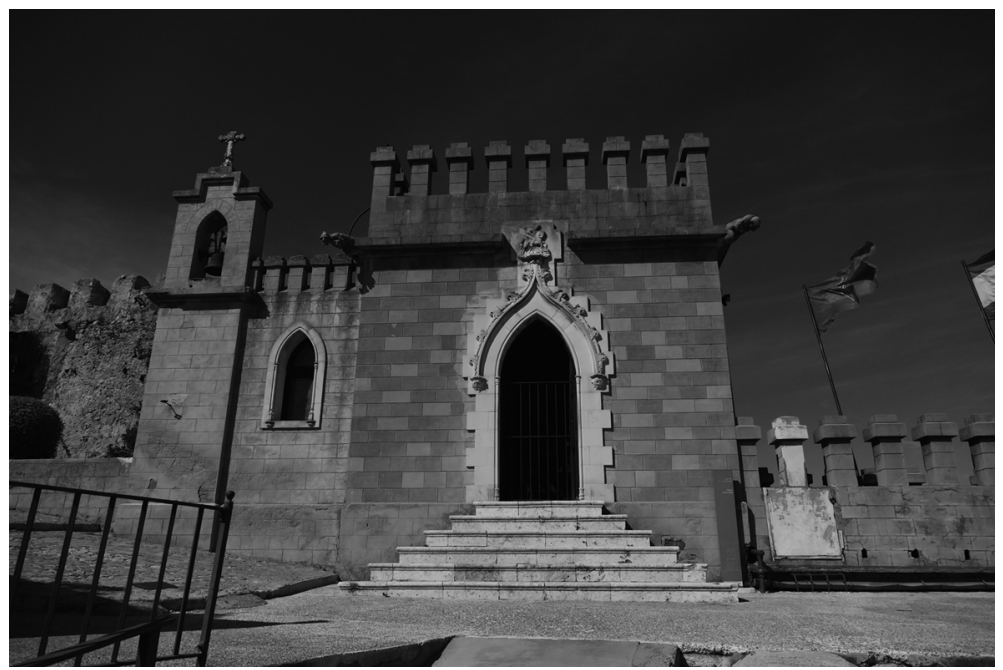

Imagen 2. Foto de la fachada. 


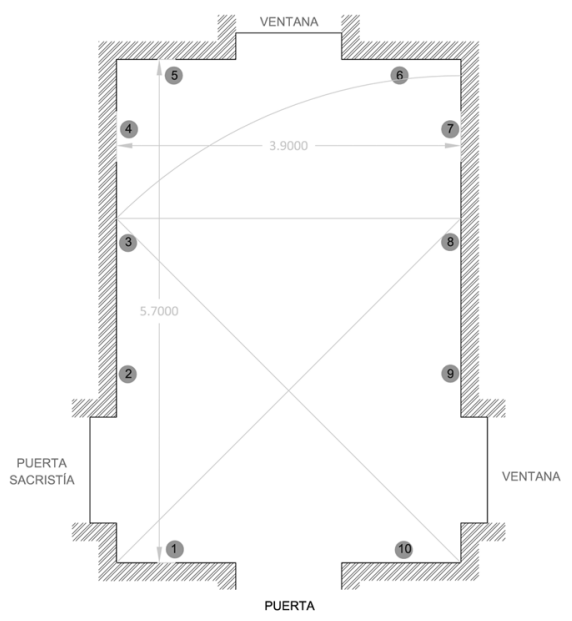

Imagen 3. Plano de la capilla. Dibujo realizado por Angel Velasco.
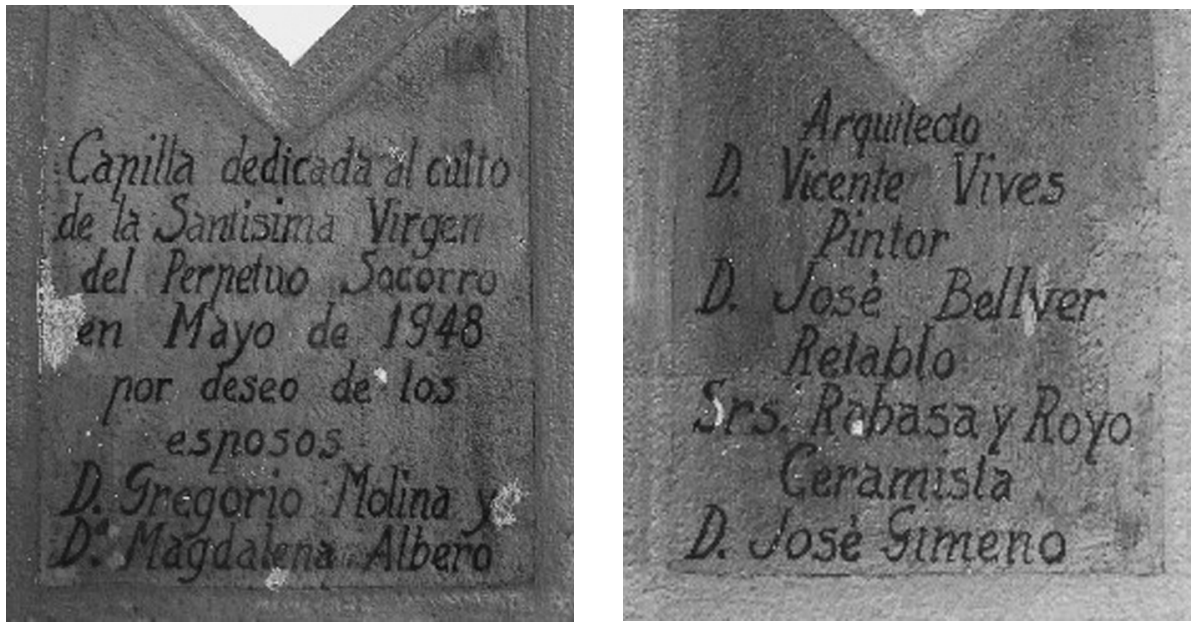

Imagen 4. Inscripciones en la pared. 
manera especular y sobre el mismo fondo pintado de ocre oscuro, la información de lo escrito es quizás más importante todavía. "Arquitecto D. Vicente Vives, Pintor D. José Bellver, Retablo Srs. Rabasa y Royo, Ceramista D. José Gimeno". Toda una declaración de la calidad perseguida con la contratación de estos artistas que en el año 1948 serían lo mejor del mercado valenciano.

Gregorio Molina Ribera nació en Banyeres (Alicante), fue muy conocido como el empresario que fundó en Xàtiva la fábrica de papel "Papelera de San Jorge". El patrón del pueblo de origen del empresario era San Jorge, a quien, como vemos, ofrece la capilla que construyó en el castillo de Xàtiva. Magdalena Albero, patrocina la capilla unida a su marido como muestra la inscripción, y ambos dedican la capilla a la Virgen del Perpetuo Socorro, por alguna razón que desconocemos.

El arquitecto que se hace cargo del proyecto, D. Vicente Vives Llorca, es conocido por que en 1957 realiza el proyecto de varios edificios en Castellón, y en 1961 trabajaba como arquitecto municipal en Benidorm, siendo el responsable de la urbanización de la Plaza nueva del castillo en ese mismo año. El pintor D. José Bellver Delmás, nació en Valencia en 1896, hijo del músico José Bellver que fue director del Conservatorio de música de Valencia durante los años 1909-1910. Estudió en la Escuela de Bellas Artes de San Carlos de Valencia, fue discípulo de Sorolla, y obtuvo por oposición el cargo de profesor de término de la asignatura de dibujo artístico y composición decorativa de las escuelas de artes y oficios artísticos. Fue director, asimismo, de las escuelas de Palencia, Valencia y Melilla y obtuvo primeros premios en concursos y exposiciones de arte. Entre sus obras destacan los retratos, paisajes y dibujos, aunque se especializó en murales realizados con la técnica del silicato potásico ${ }^{2}$, con la que posiblemente estén realizadas las pinturas de la capilla que analizamos.

Además de su obra pictórica, publicó un manual de ornamentación titulado "Curso práctico de dibujo ornamental" en el año de 1942, que constituye una guía indispensable para artesanos del momento. Entre sus murales podemos destacar los que dejó pintados en el altar mayor de la iglesia de la Santa Cruz de Valencia, realizados en 1942-1943, los murales que pinta en la Iglesia de San Lorenzo de Valencia dedicados a la Inmaculada, las pinturas de la capilla del convento franciscano de Benissa, y las pinturas realizadas en 1949 para la parroquia de San Vicente Mártir de Benimàmet (Valencia), entre otras muchas repartidas por la geografía valenciana.

2 "Técnica de pintura mural también llamada pintura al vidrio soluble, que consigue que los minerales utilizados como colorantes aglutinados con silicato potásico, sean inertes e inalterables". 


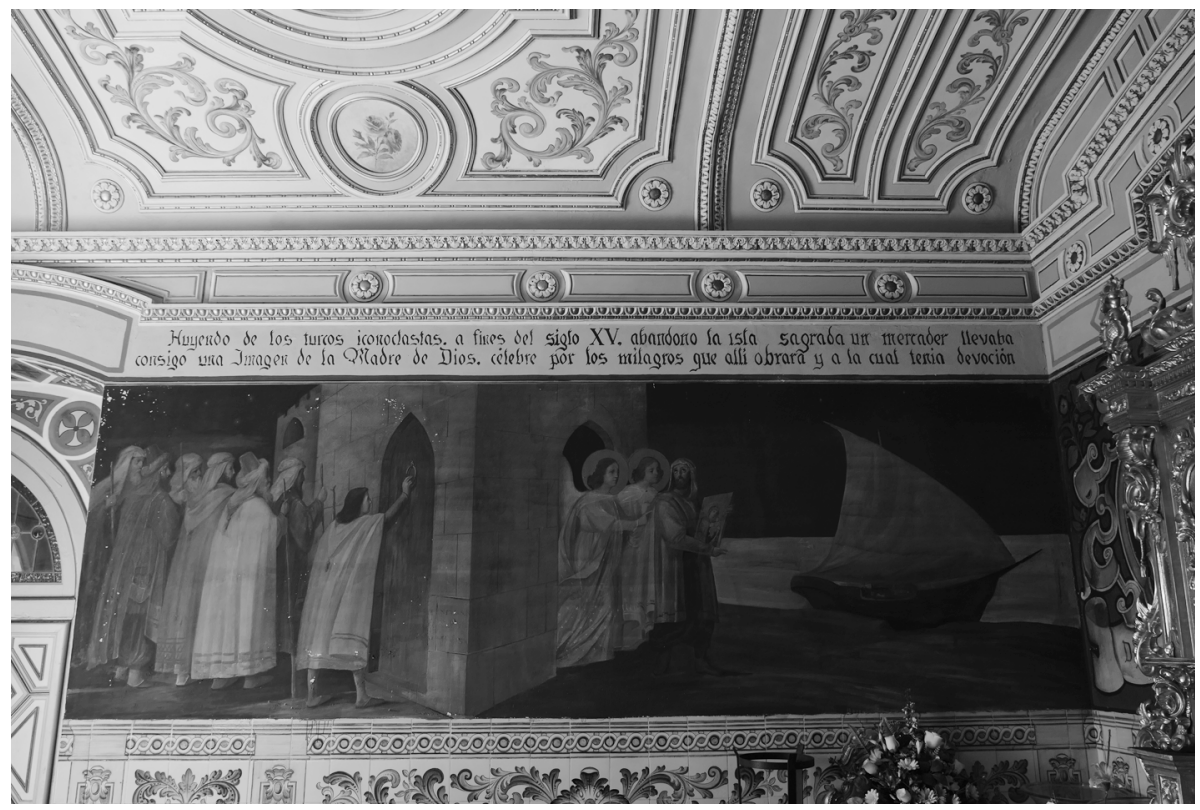

Imagen 5. Pinturas de las paredes.

Las pinturas de la capilla del Castillo de Xàtiva cuentan la historia de la imagen de la Virgen del Perpetuo Socorro, o la Virgen de la Pasión, apoyadas con frases alusivas a la tradición. Se cuenta que el icono de la Virgen del Perpetuo Socorro pertenecía a un rico y piadoso mercader de la isla de Creta. Para evitar que la pintura cayera en manos de los sarracenos, el comerciante decidió llevar la pintura a Italia. Durante el viaje en barco, se desató una violenta tormenta, y todos temieron lo peor. El mercader tomó el cuadro de nuestra señora lo sostuvo en lo alto y pidió socorro. El mar se calmó y la embarcación llegó a salvo al puerto de Roma, respondiendo así la Virgen con un milagro. De esta manera, en el muro izquierdo de la capilla y sobre la escena pintada, se sitúa la frase escrita con tipografía neogótica: "Huyendo de los turcos iconoclastas, a fines del siglo XV, abandonó la isla sagrada un mercader que llevaba consigo la imagen de la Madre de Dios, célebre por los milagros que allí obrara y a la cual tenía devoción" (Imagen 5). En el muro derecho de la capilla, y sobre la escena pintada, se sitúa la frase escrita, como la anterior, en tipografía neogótica: "La nave, en alta mar, vióse sorprendida 
por una gran tempestad y en aquel trance imploraron el auxilio de Dios y de la Virgen, Y el Socorro vino al momento: la mar se serenó y reinó la calma apareciendo en las costas de Italia".

Siguiendo con las pinturas de la capilla del Castillo, a ambos lados del altar están pintados los escudos de las dos ciudades que el promotor estima y pretende honrar, a la derecha el escudo de Xàtiva y a la izquierda el escudo de Banyeres de Mariola, su pueblo natal. Frente a estos dos motivos heráldicos, y en el muro interior, a ambos lados de la puerta, a la derecha, la figura de Alejandro VI, "que en su pontificado dedicó el culto público de Ntra. Sra. del Perpetuo Socorro", y a la izquierda la imagen de San Alfonso María de Ligorio, "Dtor de la Sta M $^{o}$ Iglesia y abogado mediador de Nuestra Señora del perpetuo Socorro".

El retablo de talla y dorado dedicado a Sant Jordi fue realizado por la firma denominada de los señores Rabasa y Royo. El taller Royo-Rabasa de Valencia se dedicó a la producción y comercialización de imágenes religiosas en tiempos de la posguerra española. Los socios que dieron nombre al taller valenciano situado en la calle Milagro $\mathrm{n}^{\circ} 4$ de Valencia, eran José Rabasa Pérez, banquero de profesión y su cuñado Antonio Royo Miralles, decorador. Los trabajos de talla y escultura realmente los componían trabajadores que no firmaban sus obras, y que estaban necesitados económicamente. Las obras acabadas salían del taller con la marca de Rabasa y Royo, aunque realmente eran los comerciales. El taller perduró hasta el año de 1953, habiendo aprovechado la avalancha de solicitudes de imágenes religiosas que se produjo después de la guerra del 36. La calidad que consiguieron los escultores en sus encargos de imaginería religiosa era excepcional realizando, sin duda, algunas de las mejores obras de imaginería valenciana del siglo $X X$.

Y, por último, el ceramista que firma el zócalo de azulejos que recorre toda la estancia no es otro que el ceramista D. José Gimeno Martínez, nacido en Manises (Valencia), en 1899. Durante una larga temporada, la cerámica valenciana se identificaba necesariamente con los productos de la fábrica de Gimeno dada la fama que llegó a adquirir en la primera mitad del siglo XX. Nació José Gimeno en el seno de una familia de Manises dedicada a la cerámica, oficio al que se dedicó toda su vida. Estudió dibujo y pintura en la academia de bellas artes de San Carlos de Valencia, hasta que a los 19 años se hace cargo de la fábrica de Juan Bautista Cabedo, "La Rosa", de Manises. Fueron profesores suyos el ceramista Antonio Peyro y el pintor y ceramista Gregorio Muñoz Dueñas. En 1925 viaja a París, pensionado para representar al estado español en la Exposición internacional de Artes decorativas. Este viaje, que realizaría junto al pintor Francisco Aguar (González, 2015), marcó un punto de inflexión en la historia de la cerámica valenciana. Gimeno reconoció el valor de las cerá- 


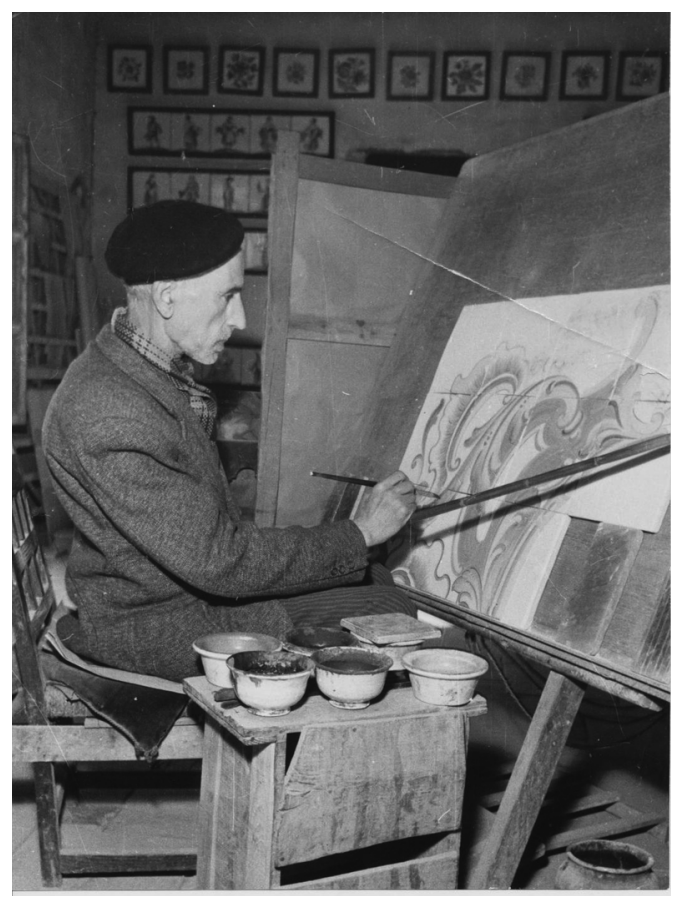

Imagen 6. El pintor Francisco Aguar pintando en la fábrica de José Gimeno en Manises. Fotografía propiedad del Museo nacional de cerámica González Martí.

micas de Manises expuestas en diversas colecciones de la capital francesa y se dedicó enteramente a la cerámica decorativa creando un estilo propio basado en el estudio de la tradición ceramista valenciana (Imagen 6).

José Gimeno muere en 1967, en Manises, habiendo recibido numerosas condecoraciones y reconocimientos. Su obra está extendida por todo el mundo, aunque en Valencia las obras más destacadas que podemos apreciar, entre otras, son el zócalo de la capilla del edificio de la Universidad en la calle de la Nave, la cocina del Museo de cerámica de Manises, y sobre todo los paneles de las salas museo de la fábrica La cerámica valenciana de Manises. En Xàtiva, al margen de las piezas existentes en colecciones privadas, fabricó el cartel de la calle taquígrafo Martí, cuyo retrato está firmado personalmente por J.Gimeno, algunas placas de indicación de calle, como la de la Plaza de Santa Tecla, o la plaza de Sant Francesc, y el panel de azulejos realizado en 
1952 para el instituto Josep de Ribera que actualmente se encuentra en el entresuelo de la escalera de dicho edificio. Sin embargo, los azulejos realizados para la capilla del castillo de Xàtiva constituyen una apreciable obra en el contexto de la cerámica patrimonial de Xàtiva, y forman el tema central de nuestro estudio.

\section{LOS AZULEJOS DEL ARRIMADERO DE LA CAPILLA DEL CASTILLO}

El zócalo de azulejos que recorre la parte baja de las paredes de la capilla del castillo de Xàtiva tiene una altura de $150 \mathrm{~cm}$, y está realizado con piezas de tamaño $15 \times 15 \mathrm{~cm}$. El diseño del dibujo está registrado sobre la obra arquitectónica teniendo en cuenta los espacios que presentan las paredes, y midiendo cada detalle para su encaje.

Se trata de un zócalo que responde a la moda de las primeras décadas del siglo XX. En los catálogos de las fábricas valencianas la fórmula que organiza el arrimadero se organiza en tres partes de bajo hacia arriba, primeramente, el Zócalo (A), la zona inferior del chapado que recoge humedades y golpes, está realizada con azulejos en azul de cobalto en primera línea al que le sigue una doble cenefa repetitiva a base de hojas polilobuladas y de friso. En segundo lugar, el Fondo (B), la zona central donde se sitúa la composición principal y se estructura en torno a un eje vertical central de simetría. Un óvalo en el centro contiene el tema alegórico elegido. Por último, la Bordura (C) la zona superior, se remata con una cenefa clásica, procedente de los tratados de Serlio y ampliamente adaptada a lo largo de todas las épocas decorativas. La fórmula compositiva $\mathrm{ABC}$, se remata a los lados con un pretendido relieve basado en columnas sombreadas que cumplen la función de separar cada argumento iconográfico (Imagen 7).

El arrimadero en su zona central va disponiendo las alegorías marianas elegidas para formar parte del programa iconográfico del promotor, y el resto repite la fórmula ornamental adaptándose a las medidas de la estancia. Las alegorías, como escudo de armas y a la vez como súplica y alabanza a María, son retomadas desde el devocionario católico antiguo y renovadas gráficamente en la pintura sobre azulejos. El recorrido lineal (Imagen 3) comenzando por la izquierda, se inicia con el ciprés $(1)^{3}$, y pasando la puerta de la pequeña sacris-

\footnotetext{
${ }^{3}$ Eclesiastés, XXIV, 13: "Como cedro me he elevado en el Líbano, como Ciprés, en el monte del Hermón".
} 


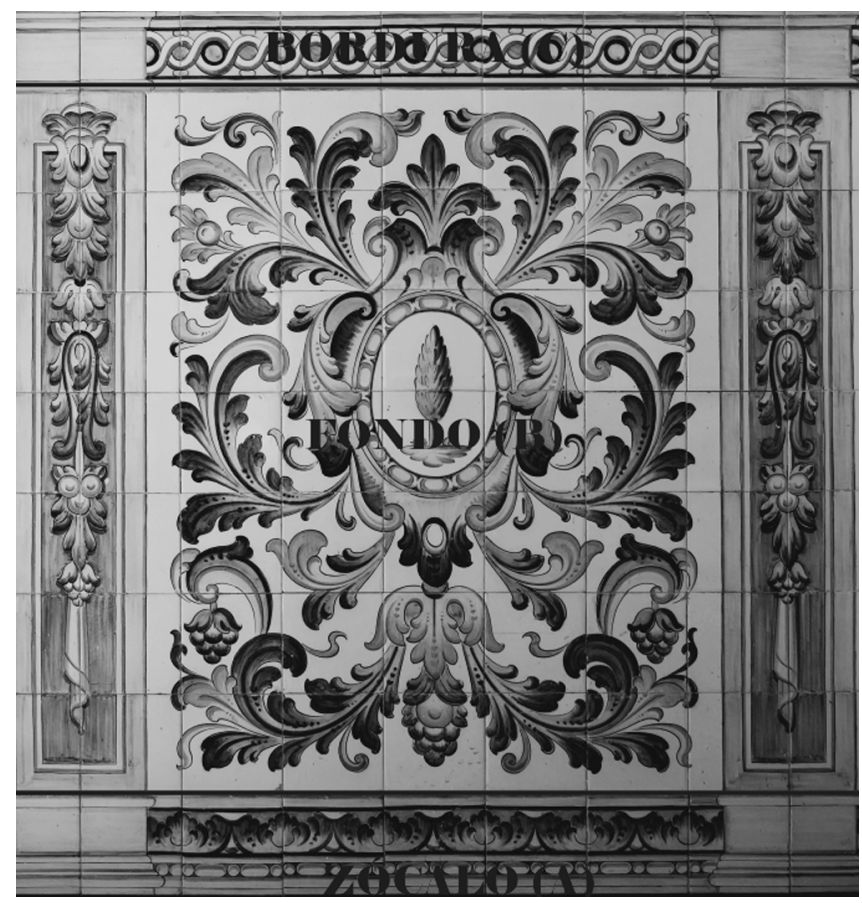

Imagen 7. Estructura del zócalo.

tía, continúa con el barco $(2)^{4}$, la Virgen del Perpetuo Socorro (3), finalizando con la ciudad de Dios (4) $)^{5}$. La pared frontal es difícil de apreciar ya que el retablo ocupa casi todo el espacio. En la zona izquierda frontal se sitúa la alegoría de los lirios $(5)^{6}$, y en la derecha la alegoría de las rosas $(6)^{7}$. Es interesante señalar que detrás del retablo hay una ventana construida, sin duda, para dotar de iluminación indirecta a la capilla, y donde el ritmo compositivo del zócalo

${ }^{4}$ María como nave de salvación.

${ }^{5}$ La Civitas Dei está inspirada en el Salmo LXXXVI, 3: "Glorias se dicen de ti, ciudad de Dios...".

${ }^{6}$ El lirium inter spinas o el lilium convalium proviene del Cantar de los Cantares II, 1-2: "Yo soy el narciso de Sarón, el lirio de los valles. Como el lirio entre los cardos, así es mi amada entre las mozas".

7 María Rosa mística. 
se detiene y se organiza ornamentalmente. Siguiendo con el recorrido, y en dirección a la entrada, el siguiente óvalo muestra el anagrama de la Virgen María (7), continúa con la imagen de San Jorge (8), justo enfrente del óvalo de la Virgen del Perpetuo Socorro. La fuente $(9)^{8}$ es la alegoría siguiente justo antes de la ventana que está decorada igual que la ventana frontal. Finaliza el trayecto la simbólica torre $(10)^{9}$, y con ello, el discurso ordenado alrededor de la espiritualidad del comitente de la pequeña capilla.

De todas las alegorías utilizadas podemos agruparlas en dos grupos, el primero, en el que se encuentran los motivos marianos, números 1, 2, 4, 5, 6, 7, 9 y 10, y otro grupo, que consideramos más personal, y de más fácil lectura, el que contiene las advocaciones de la familia, el $n^{\circ} 3$ la Virgen del Perpetuo Socorro, y el no 8 el que representa a San Jorge.

A diferencia del diseño que muestra las alegorías en el interior de un óvalo rodeado de hojas de acanto y palmas, la imagen de la Virgen y de San Jorge se presenta sostenida por dos niños tenantes a ambos lados, a modo de escudo heráldico. El óvalo dorado con la imagen de Nuestra Señora del Perpetuo Socorro (Imagen 8) está realizado en claroscuro de color carmín oscuro. Responde al modelo clásico derivado del icono bizantino venerado en Roma en la Basílica de Santa María la Mayor, excepto en la utilización de los colores. En el centro, en primer plano, la Virgen María y el niño Jesús, y alejados en segundo plano, los dos arcángeles con los instrumentos de la pasión en sus manos, el Arcángel Miguel lleva la lanza y la esponja, y el Arcángel Gabriel con la cruz ortodoxa de doble travesaño y cuatro clavos. Siguiendo a rajatabla la representación original, el pintor coloca las distintas inscripciones en idioma griego, que identifican a cada personaje. La anotación superior significa Madre de Dios, Arcángel Miguel, a la izquierda superior, Arcángel Gabriel la inscripción en el lado superior derecho, y Jesús cristo al lado del niño Jesús ${ }^{10}$. La Virgen está pintada de medio cuerpo y de pie. Viste una túnica abrochada en el cuello y un manto que la cubre desde la cabeza, y oculta sus cabellos. El niño Jesús descansa sobre el brazo izquierdo de su madre y se agarra con ambas manos a la mano derecha de María buscando protección, al contemplar los instrumentos de la

${ }^{8}$ La fuente sellada, fons signatus, frase del Cantar de los Cantares IV, 12, "Huerto cerrado eres (...), jardín cerrado, fuente sellada".

${ }^{9}$ La Turris davídica, la torre de David está extraída del Cantar de los Cantares IV, 4: "Tu cuello, la torre de David, erigida para trofeos, mis escudos penden de ella".

${ }^{10}$ MP OY [Meter Theou, Madre de Dios], en los ángulos superiores del icono. O AP M [O Arjanguelos Mijael] sobre el arcángel a la izquierda del que mira.O AP G [O Arjanguelos Gabriel] sobre el arcángel a la derecha del que mira.IC XC [Iesus Jristos] a la derecha de la cabeza de Jesús Niño. 


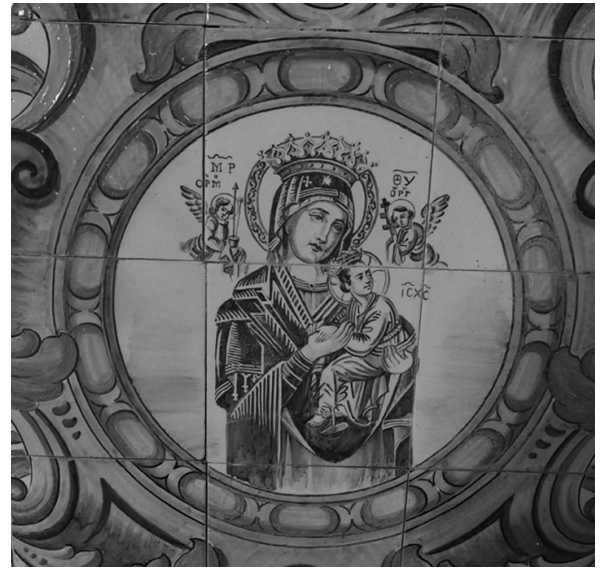

Imagen 8. Representación de Nuestra Señora del Perpetuo Socorro.

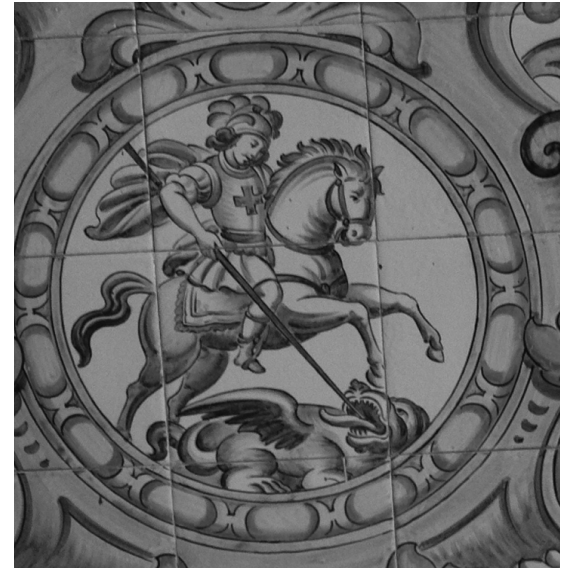

Imagen 9. Representación de San Jorge.

Pasión que le aguarda. Los arcángeles presentan a Jesús niño los instrumentos de sus sufrimientos futuros. Al contemplar esta dramática visión, el niño, en su condición de hombre mortal, se asusta y se estremece, buscando socorro en los brazos de su madre, a cuya mano se aferra con fuerza. La imagen pinta al niño de cuerpo entero vestido con una túnica y de su hombro derecho cuelga un manto. Tiene entrecruzados las piernas y lleva los pies calzados con sandalias, con la peculiaridad de que la del pie derecho queda suelta y colgando, detalle que expresaría el movimiento de las piernas, de un niño asustado.

Es destacable la utilización de los recursos pictóricos del ceramista para emular al icono original. Los pliegues dorados de la tabla cretense, se realizan mediante el esgrafiado de la pintura de manganeso dejando ver el color blanco del esmalte estannífero de base. Las carnaciones están realizadas mediante el suave sombreado que da forma sin apenas carga de colorante cerámico.

La imagen pintada en el óvalo frente a la Virgen del Perpetuo Socorro, representa a San Jorge a caballo (Imagen 9) matando al mítico dragón con una lanza y liberando así a la ciudad que éste tenía sometida. La leyenda del dragón contribuyó también a que fuera declarado patrón en diversos países y ciudades como Banyeres de Mariola (Alacant), ciudad de origen del promotor de la capilla. La representación carece de fondo, no hay paisaje, sólo interesa la visión gráfica del santo. Todo el conjunto ornamental se realiza con el mismo estarcido que se ha utilizado para la Virgen, incluidos los niños tenantes. 

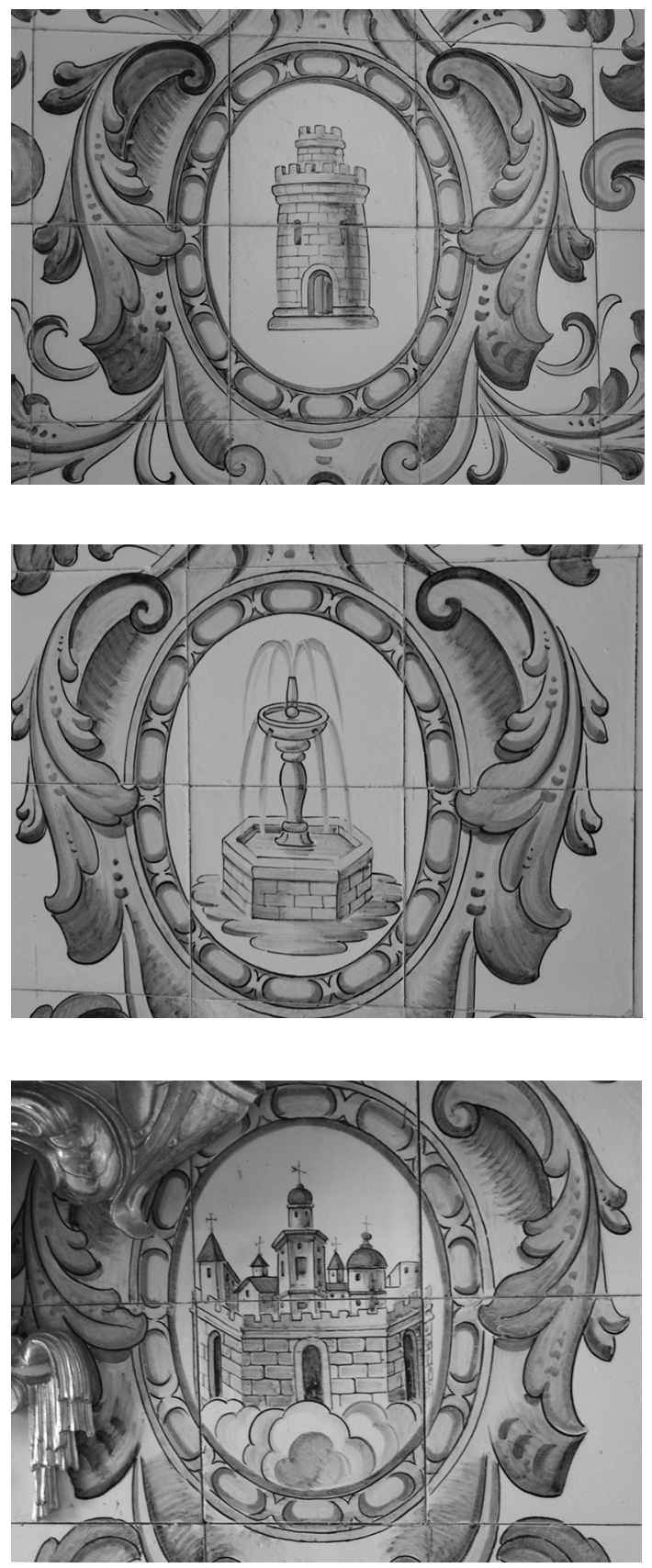

Imagen 10. Las alegorías pintadas en el zócalo de azulejos. 


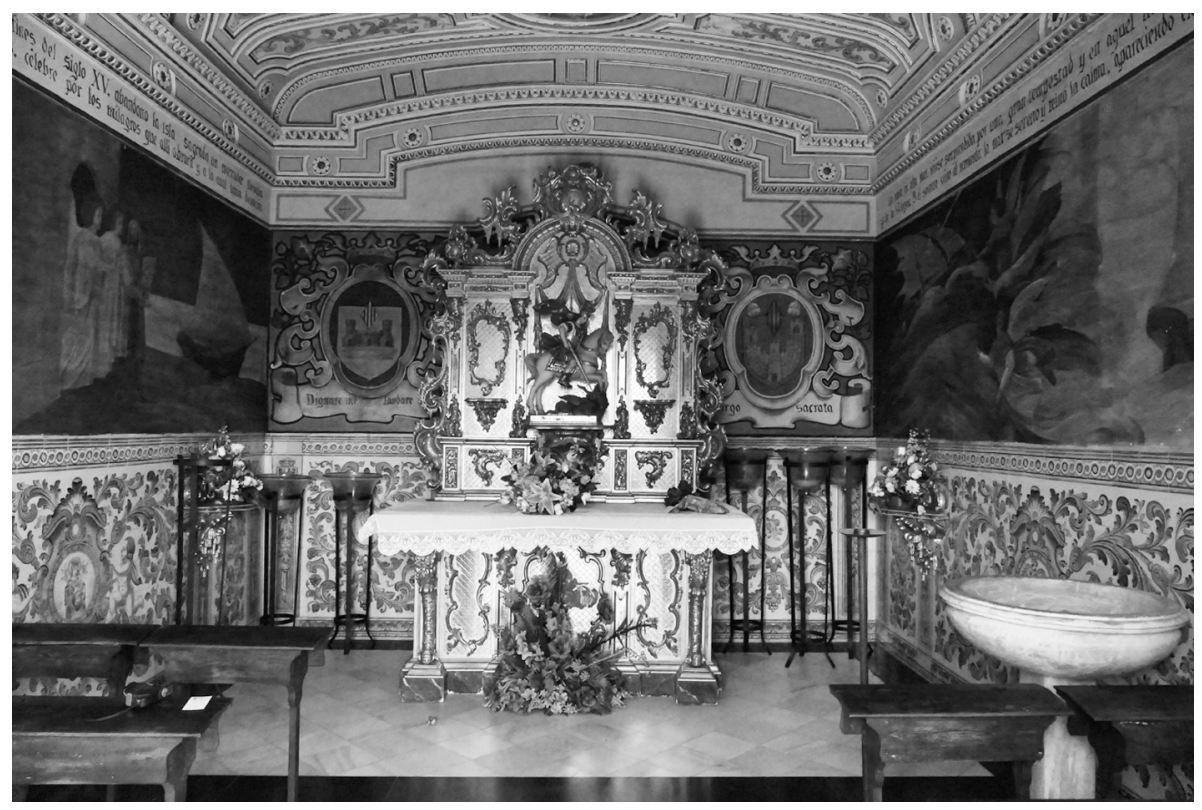

Vista general 1.

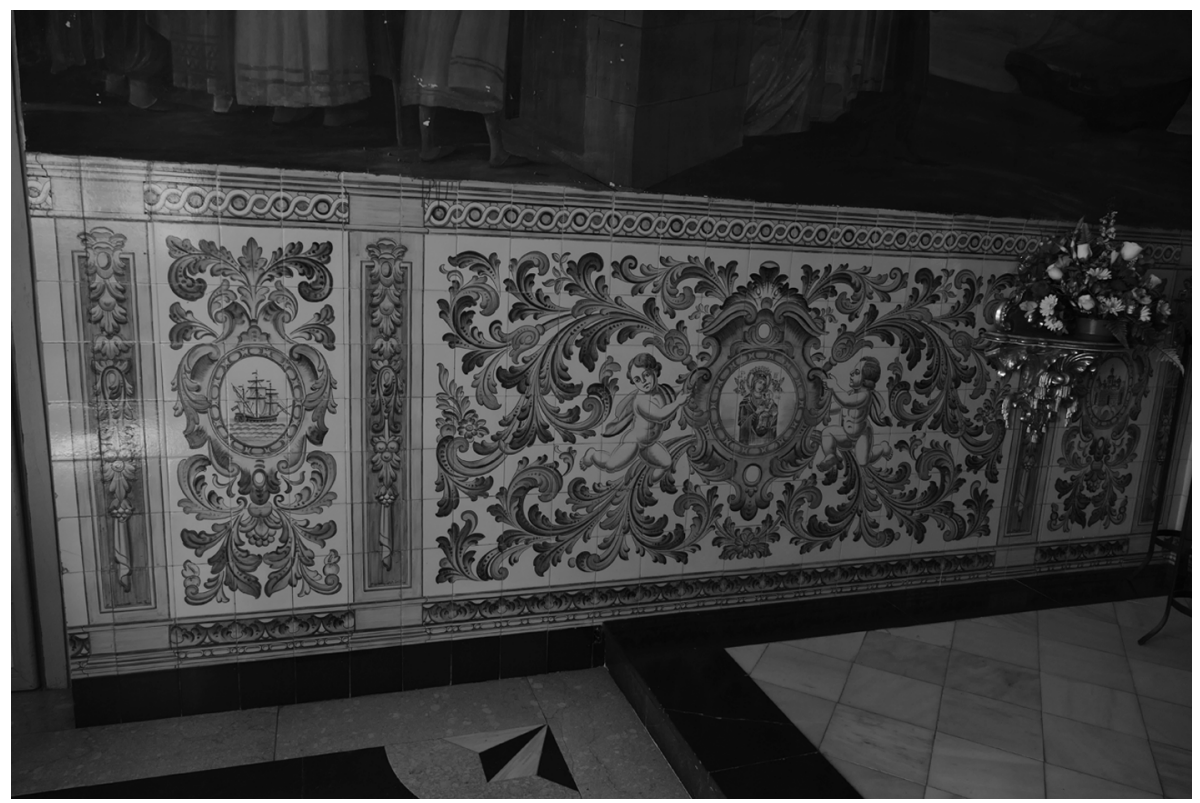

Vista general 2.

Saitabi. Revista de la Facultat de Geografia i Història, 70 (2020), pp. 107-122

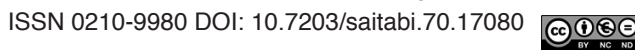


San Jorge está pintado en color carmín oscuro, un color cerámico que imita al color manganeso de siglos anteriores, al igual que la Virgen, pero perfilado en negro para resaltar el dibujo. La representación responde a la estampa clásica de la advocación, y la técnica cerámica expone el modo de pintar de Gimeno, de forma rápida y suelta, y el dibujo bien marcado, perfilado y decidido. Únicamente estos dos medallones están pintados en claroscuro, ya que el resto de las alegorías, al igual que el resto de motivos, se trazan en colores y con un perfilado sólido en color negro. En el año de 1948, la paleta de colores cerámicos está plenamente desarrollada en las fábricas de Manises, como vemos en el zócalo de Gimeno que estudiamos. Los pigmentos que utiliza están matizados al gusto del pintor, y los claroscuros se consiguen con calidad. Los colores que utiliza, bien en forma de óxidos, bien en su presentación como color cerámico, son el azul de cobalto, el verde de cobre, amarillo, naranja, ocre, carmín oscuro, negro, marrón difuminado en dos tonos para las columnas, y el óxido de manganeso con suficiente estabilidad como para utilizarlo difuminado.

La disposición de todos los elementos de la capilla del castillo, es muy ordenada. Si observamos el dibujo de la planta (Imagen 3), destaca la colocación de cada elemento y su correspondiente simétrico. La puerta de entrada situada enfrente mismo de la ventana y la puerta de la sacristía situada justo al otro lado de la ventana lateral. La medida de seis metros de largo por cuatro metros de ancho se acerca a la proporción aurea en la búsqueda de una cuidada perfección, y por tanto, del canon de belleza clásico. Los azulejos están pintados según un orden simétrico que no deja lugar para el vacío, como es fácil comprobar.

Si bien el castillo de Xàtiva se ha transformado con el tiempo en un emblema de la ciudad, la capilla que hemos descrito se expone como una pequeña joya de la primera mitad del siglo XX. José Gimeno, el ceramista, pasaba muchas temporadas en el municipio de Navalón (València), y a buen seguro que conoció en persona el castillo en su momento, y quizás, ello fue el origen de la realización de este zócalo. El trabajo de las fábricas de cerámica valenciana de la primera mitad del siglo XX está pendiente de consideración. La imagen turística de la cerámica valenciana como producto típico hasta los años 19801990, ha desembocado en la falta de interés hacia su auténtico valor, y el consecuente olvido de sus obras. La fábrica de Gimeno y sus colaboradores consiguió una gran calidad técnica en sus productos a partir de lo que desarrolló y modernizó la tradición cerámica y sus usos. Sin duda, la capilla del Castillo de Xàtiva es uno de los mejores ejemplos del trabajo de Gimeno en la ciudad de Xàtiva, que conservado en perfecto estado, constituye un importante activo patrimonial. 


\section{BIBLIOGRAFÍA}

BELENGUER CEBRIÀ, E. (2007): Jaume I i el seu regnat, Pagés.

BELLVER DELMÁS, J. (1942): Curso práctico de dibujo ornamental, América, Valencia.

CEBRIAN I MOLINA, J.LL. (2009): "El plafó del III centenari de Ribera i les obres de J. Gimeno a Xàtiva". En 75 aniversari de la creació de L'institut IES Josep de Ribera, 2009, pp. 37-40.

GONZÁLEZ TERUEL, M. (coord.) (2015): La colección de azulejos de Francisco Aguar (1900-1970), E-DitARX.

LLORENÇ, A. (ed.) (1986): Món i misteri de la Festa d'Elx, Generalitat valenciana, Alboraia.

LLORENS HERRERO, M.; CATALÁ GORGES, M.A. (2007): La Inmaculada Concepción en la historia, la literatura y el arte del pueblo valenciano, Biblioteca valenciana, Valencia.

MORENO ROYO, J. M ${ }^{\mathrm{a}}$ (1983): Manises retazos de su historia, Seguí, Alzira.

PÉREZ GUILLÉN, I.V. (2004): Las azulejerías de la Habana, Universitat de València.

SARTHOU CARRERES, C. (2009): El alcázar setabense, Ulleye, Xàtiva. 